\title{
Origin and development of the thoughts on military keynesianism during 1936-2012
}

\author{
Luboš ŠTANCL ${ }^{1}$, Vendula HYNKOVÁ
}

\begin{abstract}
The aim of the paper is to show how the thoughts of military Keynesianism have been developed and to define the role of military Keynesianism. First, the term 'military Keynesianism' will be introduced and its birth in the history of economic development will be dated and explained. Second, the development of the thoughts of military Keynesianism and also the development of the military-industrial complex will be described and the main different views on the application of military Keynesianism policy will be included. Finally, the authors will try to interpret opinions on the application of military Keynesianism during the economic recession, 2008-2012.

Key words: military Keynesianism, militarization, military Keynesianism policy, military-industrial complex

JEL classification: E6, B5, H5
\end{abstract}

\section{Introduction}

The term "Military Keynesianism" is related to increasing military expenditures in order to improve economic situation, more exactly to enhance the real gross domestic product (GDP). Firstly, let us have a look at the situation of military spending in the world, regardless of whether there is a state of war in a region or just increased military spending for a certain purpose(s). According to the Stockholm International Peace Research Institute (SIPRI), world military expenditure in 2012 was estimated to have been $\$ 1.756$ billion, that represents 2.5 percent of world gross domestic product and it is about \$249 for each person on our planet. [1] What we can observe nowadays is that there is a shift in global spending, in particular, from the West to Eastern Europe and the developing world (mainly North Africa). As we shall see in Table 1, due to continuing economic recession and rising government debt, states in North America, Western and Central Europe have tried to reduce government spending, including military expenditures (North America -5.5\%, Western and Central Europe -1.6\%). In contrast, there are regions in the world where the rate of growth is relatively high and accelerated (bolded in Table 1): North Africa (7.8\%), Central America and the Caribbean (8.1\%), East Asia (5\%), South East Asia (6.0\%), Eastern Europe (15\%) and the Middle East (8.3\%). The 15\% rise in Eastern Europe is mostly the result of the Russia's State Armaments Program started in 2011 and a further rise is expected to fullfil the program completely in 2020.

\footnotetext{
1 CSc, lubos.stancl@unob.cz

2 Ph.D., vendula.hynkova@unob.cz
} 
Luboš ŠTANCL, Vendula HYNKOVÁ: Origin and development of the thoughts on military keynesianism...

Table 1. World military spending, 2012

\begin{tabular}{|c|c|c|}
\hline Region & $\begin{array}{l}\text { Spending } \\
\text { (\$ b.) }\end{array}$ & Change \% \\
\hline Africa & 39.2 & 1.2 \\
\hline North Africa & 16.4 & 7.8 \\
\hline Sub-Saharan Africa & 22.7 & -3.2 \\
\hline Americas & 782 & -4.7 \\
\hline Central America and the Caribbean & 8.6 & 8.1 \\
\hline North America & 708 & -5.5 \\
\hline South America & 65.9 & 3.8 \\
\hline Asia and Oceania & 390 & 3.3 \\
\hline Central and South Asia & 59.8 & -1.6 \\
\hline East Asia & 268 & 5.0 \\
\hline Oceania & 28.2 & -3.7 \\
\hline East and South East Asia & 33.7 & 6.0 \\
\hline Europe & 407 & 2.0 \\
\hline Eastern Europe & 100 & 15 \\
\hline Western and Central & 307 & -1.6 \\
\hline Middle East & 138 & 8.3 \\
\hline World total & 1756 & -0.4 \\
\hline
\end{tabular}

The figures are in current (2012) US dollars. [1]

East and South Asia also showed a rise of 5 and 6\%. We have to stress China and its rapid military build-up that seems to be disconcerting mainly for Japan, such as when China took actions allegedly to back its claims to Japanese-held islands in the East China Sea. Japan started to enhance its military spending and to build up offensive military power. According to SIPRI Yearbook 2013 statistics, China is the second highest military spender and Japan the fifth highest spender in 2012.

If we consider reasons for increasing military expenditures, there are several arguments - the state of war, defense security policy or deterrent policy, and there is a reason where increasing military power is considered a "stimulant" for economic growth. This argument in favor of military expenditures has become well-known as "Keynesian Militarism” or "Military Keynesianism”, when military expenditures serve as an effective instrument of fiscal macroeconomic policy. Nowadays we usually understand military Keynesianism as an economic policy that uses massive military expenditures to attain economic growth. And there are, of course, positive and negative evaluations and many intense discussions are held about the influence of massive military spending. Now we take a look into the roots or origins of military Keynesianism. 


\section{Roots of military Keynesianism}

The roots of military Keynesianism are included in Keynesian thought when English economist Sir J. M. Keynes was solving the causes of the "Great Depression" and suggested enhancing government spending. J. M. Keynes was aware of military expenditures place within the additional effective demand stimulating economic growth. He understood military spending as a public demand impulse helping the economy, but was not able to generate a sufficient level of private investment and consumption and encourage full employment.

While in $1936 \mathrm{~J}$. M. Keynes talked about military spending as a theoretic example of how to increase aggregate demand, four years later, after a less than effective "New Deal” policy, he pointed out the war could improve the economy and enhance employment: "It appears to be politically impossible for a capitalistic democracy to organize expenditure on a scale necessary to make the grand experiment which would prove my case except in war conditions". [2:159] [3: 129-130] As well he added that military spending had to be enormous. [4] Preparing for unavoidable war without casualties and damage can positively influence the economy.

Economist Michal Kalecki was the first who was concerned more deeply with military expenditures influence on economic growth. In 1943 he demonstrated his military spending model using the situation of Nazi Germany. He considered tremendous military expenditures more effective than other government expenditures because of the danger of labor unions and employee empowerment. In his version the government should accentuate nationalism and create a need for defense. Massive military expenditures helped to recover the German economy and overcome global recession, although the economic growth was a "secondary product”. Thus the Kalecki concept became inspirational for US right-wing politicians.

The United States engaged in World War II at the end of the "Great Depression". Many economists and politicians believed that it was no "New Deal”, but the war that dug the US economy out of recession. Economist Robert Lekachman noticed: "The war pointed at a sharp Keynesian moral. As a public works project, all wars (before the nuclear era) are ideal. Since all war production is sheer economic waste, there is never a danger of producing too much”. [5]

Table 2. U. S. military expenditures during World War II

(mil. dollars, at constant prices of 1940) [6]

\begin{tabular}{|c|c|c|c|c|c|c|c|c|c|}
\hline \multirow[t]{2}{*}{ Year } & \multicolumn{2}{|c|}{ Nominal GDP } & \multicolumn{3}{|c|}{$\begin{array}{l}\text { Government } \\
\text { Expenditures }\end{array}$} & \multicolumn{4}{|c|}{ Military Expenditures } \\
\hline & (USD) & $\begin{array}{c}\text { Change } \\
\text { (\%) }\end{array}$ & (USD) & $\begin{array}{c}\text { Change } \\
\text { (\%) }\end{array}$ & $\begin{array}{c}\text { Share } \\
\text { of } \\
\text { GDP } \\
(\%)\end{array}$ & (USD) & $\begin{array}{c}\text { Change } \\
(\%)\end{array}$ & $\begin{array}{c}\text { Share } \\
\text { of } \\
\text { GDP } \\
(\%)\end{array}$ & $\begin{array}{c}\text { Share } \\
\text { of } \\
\text { GE } \\
(\%)\end{array}$ \\
\hline 1940 & 101.4 & & 9.47 & & 9.34 & 1.66 & & 1.64 & 17.53 \\
\hline 1941 & 120.67 & 19.00 & 13.00 & 37.28 & 10.77 & 6.13 & 269.28 & 5.08 & 47.15 \\
\hline 1942 & 139.06 & 15.24 & 30.18 & 132.15 & 21.70 & 22.05 & 259.71 & 15.86 & 73.06 \\
\hline 1943 & 136.44 & -1.88 & 63.57 & 110.64 & 46.59 & 43.98 & 99.46 & 32.23 & 69.18 \\
\hline 1944 & 174.84 & 28.14 & 72.62 & 14.24 & 41.54 & 62.95 & 43.13 & 36.00 & 86.68 \\
\hline 1945 & 173.52 & -0.75 & 72.11 & -0.70 & 41.56 & 64.35 & 2.51 & 37.19 & 89.49 \\
\hline
\end{tabular}


The US economy had expanded during 1941-1945. Gross domestic product increased markedly from 88.6 Mld USD in 1939 to 135 Mld USD in 1944 (measured at constant prices of 1939). Military production as a percent of GDP intensified rapidly from 2\% in 1939 to 40\% in 1943. [7]

World War II not only helped the U.S. economy overcome economic crisis, but also improved the partnership among the government, private sector and labor unions. This was a positive influence in the following years and enhanced production. The U.S. economy was propelled by military industry expansion and provided the U.S. immense economic advantage in comparison with the allies and rest of the world. The U.S. government became an administrator of the strongest economy in the world and gradually a center of the after-war world economy.

States preparing for war have to carry out the economic conversion of civilian production to military production, extend armament industry capacities and other production capacities and services. The economy is experiencing recovery, but enormous military expenditures create or deepen state budget deficits. J. M. Keynes considered wars extraordinary situations that enabled reaching almost full employment. Thus he supported increasing armament production and militarizing the economy and he thought that the militarization process would not necessarily invoke serious negative consequences, including war. However, many economists disagree and believe military expenditures are the least effective way to allocate budget resources, because they do not invest in profitable infrastructure building.

\section{Military Keynesianism and military-industrial complex}

Since 1944 attention has been paid to the conversion of military production to civilian production. At the end of World War II economists and politicians were afraid of the "Great Depression” continuing. So they hoped the Cold War would start providing the expansion of military prosperity, because disarmament and peace could have caused economic and political problems. ${ }^{3}$ In 1950 The U. S. National Security Council submitted a secret report to the president of the U.S. This document designated NSC-68 [8] was unclassified in 1977.

The military Keynesianism Policy supporting the Korean and Vietnam War encouraged rapid military spending, not only in the U.S., but also in the rest of the world. Table 3 demonstrates military expenditures during the period 1949-1968. The U.S. military spending increased very sharply during this time and the U.S. government made efforts to hold the strong position and confirm investor's and consumer's confidence.

3 Chester Bowles added: „, One of the first things we must realize is that in the 1930's we never really did find the answer to full employment. Only the defense program in 1940 put our people to work and only the war and the cold war that followed have kept them at work“. In [4] 
Luboš ŠTANCL, Vendula HYNKOVÁ: Origin and development of the thoughts on military keynesianism...

Table 3. Military expenditures trend during the period 1949-1968

(mil. USD, at constant prices of 1960) [9: 200]

\begin{tabular}{|c|c|c|c|c|c|c|c|c|c|}
\hline & $\mathbf{1 9 4 9}$ & $\mathbf{1 9 5 1}$ & $\mathbf{1 9 5 3}$ & $\mathbf{1 9 5 5}$ & $\mathbf{1 9 5 7}$ & $\mathbf{1 9 6 1}$ & $\mathbf{1 9 6 2}$ & $\mathbf{1 9 6 6}$ & $\mathbf{1 9 6 8}$ \\
\hline $\begin{array}{c}\text { United } \\
\text { States }\end{array}$ & 16629 & 37781 & 54409 & 44428 & 46843 & 47335 & 51203 & 57951 & 68213 \\
\hline NATO & 23905 & 50231 & 70287 & 58985 & 62382 & 63689 & 69101 & 76776 & 87755 \\
\hline $\begin{array}{c}\text { Soviet } \\
\text { Union }\end{array}$ & 8800 & 10709 & 11978 & 11888 & 10747 & 12889 & 14111 & 14889 & 18556 \\
\hline $\begin{array}{c}\text { Warsaw } \\
\text { Pact }\end{array}$ & 13600 & 15509 & 16778 & 16688 & 16235 & 20712 & 22651 & 25148 & 31156 \\
\hline World & 43659 & 74094 & 95291 & 84013 & 87848 & 95623 & 104311 & 119492 & 138851 \\
\hline
\end{tabular}

Moreover, U.S. Keynesian macroeconomic policy was supported by industrial corporations and labor unions. Major industrial corporations got very lucrative government contracts and strengthened their position. Strong labor unions agreed to a high level of military expenditures in order to keep the social contract and minimize the number of strikes.

Increasing volumes of military expenditures deepened the militarization of economies and military-industrial complex expansion. ${ }^{4}$ US President Dwight D. Eisenhower warned against this effect in 1961. He also started to use the term "military-industrial complex". He pointed out the danger of the militarization of the economy and potential threats. [10] The main idea is that military production should comport with the need of the defense of the country.

At present we distinguish two types of military Keynesianism. The first type, according to P. Custers, [11] was implemented during the R. Reagan and George W. Bush administrations. Military spending is perceived as the main factor of economic growth. The second type was carried out during the B. Clinton administration. The second type is characterized by government contracts stimulating investment in defense and the civilian sector. In this second instance military spending is not the main factor of economic growth.

\section{Military Keynesianism and its criticism}

The critics point out the negative social consequences of military Keynesianism policy. Excessive armament during peace can provoke nations to enter war. Moreover, there is the danger of militarization and nationalism. Enormous military expenditures speed up the increasing influence of the military-industrial complex. For instance, the contracts with the Pentagon enabled the formation and development of new industries and supporting corporations. One of the biggest suppliers for the U.S. Government Lockheed Martin profits mainly from government contracts and exporting weapons. [12]

4 The term "Military-industrial complex" was firstly described by American Philosopher Ch. W. Mills in 1956. The main idea is that there are elites in the industrial state, including cooperative (economic), political and military bureaucracy unified by the collective interest of the public policy. The phrase "Military-industrial complex" was firstly used by Dwight D. Eisenhower. 
Luboš ŠTANCL, Vendula HYNKOVÁ: Origin and development of the thoughts on military keynesianism...

Table 4. Top 10 Armament Corporations, excluding China (2011) [13]

\begin{tabular}{|c|c|c|c|}
\hline & Corporation (State) & $\begin{array}{c}\text { Selling weapons } \\
\text { (mil. USD) }\end{array}$ & $\begin{array}{c}\text { Profit } \\
\text { (mil. USD) }\end{array}$ \\
\hline 1. & Lockheed Martin (U.S.) & 36270 & 2655 \\
\hline 2. & Boeing (U.S.) & 31830 & 4018 \\
\hline 3. & BAE Systems (GB) & 29150 & 2349 \\
\hline 4. & General Dynamics (U.S.) & 23760 & 2526 \\
\hline 5. & Raytheon (U.S.) & 22470 & 1896 \\
\hline 6. & Northrop Grumman (U.S.) & 21390 & 2118 \\
\hline 7. & EADS (Europe) & 16390 & 1442 \\
\hline 8. & Finmeccanica (Italy) & 14560 & -3206 \\
\hline 9. & L-3 Communications (U.S.) & 12520 & 956 \\
\hline 10. & United Technologies (U.S.) & 11640 & 5347 \\
\hline
\end{tabular}

The military-industrial complex represents interest and personal connections with state bureaucracy, political elite and military-industrial corporations. Thus it is very hard for the government to decrease military spending or eliminate state budget deficits. As a result, there may be a continual cycle of war and peace changing and related to government spending.

There is a discussion about the contribution of investment in military research and development. Some economists suppose that military R\&D is less effective than civilian R\&D and use the examples of the Japanese and German economy. H. Garrett-Peltier and R. Pollin point out that a one dollar investment in the civilian sector brings more jobs than one dollar investment in defence. [14]

The critics of military Keynesianism usually use the concept created by Frédéric Bastiat called "The parable of the broken window". In the theory he describes a shopkeeper whose window is broken by his young son, and who has to pay for a glazier to fix his window. It brings some transactions into the economy and increases money circulation. Sir M. Keynes saw that it was worth building, for example, totally useless pyramids in order to stimulate the economy, raise aggregate demand, and encourage full employment. But the main idea is that society loses the value of things which are uselessly destroyed and that we must take into account the opportunity cost. It means that the shopkeeper could have spent money on something else, but he was forced to spend his money on a new window. So military Keynesianism also ignores the opportunity cost.

Independent economists usually oppose the idea that high level military spending invokes high percentage tax rate cuts for the disposable incomes of householders and profits of corporations. By this they emphasize the long-run effects of military Keynesianism policy.

\section{World military spending during 2008-2012}

According to SIPRI, global military expenditure in 2008 showed an increase of about 4 per cent in real terms compared to 2007. US military expenditure increased, mostly due to the wars in Afghanistan and Iraq, but at the expense of expanding stat budget deficit, and also the mortgage crisis started in the United States. Military spending in Western and Central Europe 
was an almost constant average, but Russia continued to enhance its military expenditures to fulfil plans in the future, despite economic problems. States, such as China, India, South Korea, Taiwan and Brazil, increased military spending, but military spending in the Middle East fell slightly, excluding Iraq where there was a large rise. At the low point of the world economic recession we could observe some efforts to help the U.S. economy and avoid the crises via the policy of military Keynesianism. Here is a citation concerning the RAND Corporation's proposal, presented to the Pentagon in October 30, 2008.

"...the RAND Corporation recently presented a shocking proposal to the Pentagon in which it lobbied for a war to be started with a major power in an attempt to stimulate the American economy and prevent a recession."

“...RAND suggested that the $\$ 700$ billion dollars that has been earmarked to bailout Wall Street and failing banks instead be used to finance a new war which would in turn re-invigorate the flagging stock markets." [15]

The RAND Corporation (www.rand.org) is a nonprofit institution that helps improve policy and decision-making through research and analysis. One of its core research areas is national security. According to the article, the Corporation is allegedly connected with the U.S. military-industrial complex and this tie could be a useful reason to start a policy of military Keynesianism. The thought consequently caused alarming debates, mainly in China, Japan, Russia and North Korea.

In 2009 despite the world recession, almost all regions registered an increase in military spending, except the Middle East. According to SIPRI, the global military expenditures increased by $6 \%$ in real terms compared to the previous year. Now we can speculate whether the idea of military Keynesianism was integrated to counteract the classical recession (i.e. decreasing aggregate demand in the economy, inducing deflation and lower output). Notwithstanding, smaller economies cut military spending, nine of the top ten spenders in the world increased their military budget. The world economic recession caused a fall in resource revenues (mainly from oil production) in some countries, but not so much on average.

The continuing recession in developed countries did not allow spending much on the defense sector in 2010. Economic growth is a key enabler; military spending is not in many cases able to grow faster than gross domestic product (GDP). In countries, such as China, Brazil, India, Russia or South Korea, the GDP grew almost rapidly and military powers were developed. The causes can be current or potential conflicts, as well as a perception of military power. Some countries had to change the budget priorities in favour of or against military spending. This is a very controversial topic under conditions of increasing social needs in a country.

In 2011 there was no increase in world military expenditures and it was the first fall since 1998. Compared with 2010, in real terms military spending remained almost unchanged. Mainly the continuing economic and financial crises in developed countries influenced government spending. Avoiding budget deficits the governments in Western and Central Europe, particularly, decided to cut military spending. In the U. S. the decade-long rise in military spending appeared to be ending (a result of the end of the Iraq War, the winding down of the Afghanistan War and also budget deficit-reduction measures), however the fall in US military spending in real terms was not as substantive as in Europe.

World military expenditure in 2012 fell by 0.4 per cent in real terms versus in 2011 . That was the first fall since 1998. US military spending declined by 5.6 per cent in real terms in 
2012, together with the year 2011, which might be a consequence of a post-war situation. The trend and future level of US military spending was a main topic for political debates. Under conditions of rising government debt it was an unwanted situation for the military. In Western and Central Europe, states continued to cut military spending. In contrast, the rise in military spending followed in Eastern Europe and the developing world (higher rates of growth in the Middle East and North Africa, as expected). And Russia's military expenditures accelerated, because Russia has tried to fulfil its ambitious State Armaments Programme.

\section{Conclusion}

This paper has dealt with an introduction to military Keynesianism as an instrument of fiscal policy, the birth of this idea in Keynesian though when the positive effect of massive military expenditures on economic growth was expected. The authors explained two types of military Keynesianism and the role of the military industrial complex. The criticism of military Keynesianism was mentioned to point out the negative consequences for society. In the last part, main trends in military spending were described and also macroeconomic problems influencing the military expenditures in many countries.

Mainly during the post-war era, most advanced countries made efforts to use the military Keynesianism policy and build military power and develop an armament industry. The main goal was to stabilize the economy and enhance production. Thereby the militarization of economies became stronger and stronger. But we can observe these days that some countries increase their military expenditures to build up their army to compete with foreign military powers, and there is still a danger of militarizing economies.

Contrary to the civilian sector, the motion of military industrial development lies in the political sphere. As the analyses of the military-industrial complex shows the military-industrial complexes existence is based on a continuing symbiosis between the government (political elites) and armament corporations. The symbiosis is also an instrument for strengthening government power and re-election. The empowered political elites improved the opportunities for allocation of resources in the defense sector and increased their abilities of putting through their interests, including a combination of military and civilian Keynesianism.

There is a need to continuously examine the consequences of military Keynesianism policy and explore the relationship between military expenditures and economic growth (including the long-run effects). In addition, we should examine not only economic aspects, but also political, social and other aspects concerning the militarization of the economy.

\section{Reference}

[1] SIPRI: 3. Military expenditure. In. SIPRI Yearbook 2013: Armaments, Disarmament and International Security. Oxford: Oxford University Press, 2013. [online] http://www.sipri. org/yearbook/2013/03 (Available at: 0101 2014)

[2] KEYNES, J. M.: The United States and the Keynes Plan. The New Republic, CIII 3 Part 2 (29 07 1940)

[3] DUDLEY, D.: The Economics of John Maynard Keynes: The Theory of a Monetary

Economy. New York: Prentince-Hall, 1948. DOI: https://

doi.org/10.1177/000271624926600131 
Luboš ŠTANCL, Vendula HYNKOVÁ: Origin and development of the thoughts on military keynesianism...

[4] MINTZ, A., HICKS, A.: Military Keynesianism in the United States, 1949-1976: Disaggregating military expenditures and their determination, American Journal of Sociology 902 (1984), 411-417. DOI: https://doi.org/10.1086/228086

[5] BARLETT, B.: Keynesian War Stories (Notall government spending is alike). [online] http://old.nationalreview.com/nrof_barlett200412220847.asp (Available at: 0308 2010)

[6] TASSAVA, C. J.: The American Economy during World War II. [online] http://eh.net/ encyclopedia/article/tassava.WWII (Available at: 1205 2010)

[7] TASSAVA, C. J.: The American Economy during World War II. [online] http://eh.net/ encyclopedia/article/tassava.WWII (Available at: 1210 2006)

[8] NATIONAL SECURITY COUNCIL: NSC 68: United States Objectives and Programs for National Security. Washington, April 14, 1950. [online] http://www.fas.org/irp/offdocs/nschst/nsc-68-cr.htm (Available at: 0806 2010)

[9] SIPRI: SIPRI Yearbook of World Armaments and Disarmament 1968/69. London: General Duckworth \& Co Ltd, 1969.

[10] EISENHOWER, D. D.: Military-Industrial Complex Speech. Public Papers of the Presidents, Dwight D. Eisenhower, 1961, 1036-7.

[11] CUSTERS, P.: The U.S. Economy under the Obama Presidency - Beyond Military Keynesianism? (A Commentary After Barack Obama's Election As President of the US. London: Merlin Press, 2007. [online] http://www.networkideas.org/news/dec2008/news19_ US_Economy.htm (Available at: 1006 2010)

[12] BARRY, T.: Synergy in Security (The Rise of the National Security Complex. [online] http://www.dollarsandsencse.org/archives/2010/0310barry.html (Available at: 1006 2010)

[13] SPIRI: The SIPRI Top 100 arms-producing and military services companies in the world excluding China, 2012 [online] http://www.sipri.org/research/armaments/production/ Top100/2011 (Available at: 0101 2014)

[14] GARRET-PELTIER, H., POLLIN, R.: The U.S. Employment effects of Military and Domestic Spending Priorities: An Updated Analysis. Amherst: Political Economy Research Institute University of Massachusetts, 2009. [online] http://www.peri.umass.edu/fileadmin/ pdf/published_study/spending_priorities_PERI.pdf (Available at: 1006 2010) DOI: https:// doi.org/10.2190/HS.39.3.b

[15] WATSON, P. J., DAI, Y.: RAND Lobbies Pentagon: Start War to Save U.S. Economy. [online] http://www.infowars.com/rand-lobbies-pentagon-start-war-to-save-us-economy (Available at: 0106 2010) 